\title{
Effects of Addition of Tomato Powder on Colour, Antioxidant, and Antimicrobial Traits of Pork Jerky during Storage
}

\author{
II-Suk Kim, Sang-Keun Jin, Cheorun Jo ${ }^{1}$, Mooha Lee ${ }^{2}$, Mi-Ra Yang, Ji-Hye Kim³ ${ }^{3}$ and Suk-Nam Kang* \\ Department of Animal Resources Technology, Gyeongnam National University of Science and Technology, \\ Jinju 660-758, Korea \\ ${ }^{1}$ Department of Animal Science and Biotechnology, Chungnam National University, Daejeon 305-764, Korea \\ ${ }^{2}$ Department of Agricultural Biotechnology, Seoul National University, Seoul 151-921, Korea \\ ${ }^{3}$ Department of Oriental Pharmacy, Woosuk University, Chunbuk 565-701, Korea
}

\begin{abstract}
The aim of this study was to investigate the effects of the addition of tomato powder $[1.0 \%$ (T1), $1.5 \%$ (T2) and $2.0 \%$ (T3)] on pork loin jerky with aerobic package during storage at room temperature. The T3 sample showed lower $(p<0.05)$ $\mathrm{pH}$ value and higher $(p<0.05)$ water activity than the control during storage. Total plate counts of treated samples $(\geq 1.20 \mathrm{Log}$ $\mathrm{CFU} / \mathrm{g})$ were significantly $(p<0.05)$ lower than the control $(1.46 \mathrm{Log} \mathrm{CFU} / \mathrm{g})$ during storage. With the increase of the tomato powder concentration the lightness $\left(\mathrm{L}^{*}\right)$ of the jerky decreased, except at day 30 of storage, but the redness (a*) and yellowness $\left(b^{*}\right)$ increased significantly $(p<0.05)$ during storage. T3 had higher values for hardness and cohesiveness but lower for springiness, gumminess and chewiness than others at day 40 of storage. However, there were no significant differences in TBARS values among the samples during storage. In sensory properties, the color scores of T3 was significantly $(p<0.05)$ higher than that of control at day 40 of storage. These results suggested that $2.0 \%$ tomato powder could be used to improve the redness and extend the shelf-life of jerky with increasing water activity, providing the consumer with food containing natural colorant.
\end{abstract}

Key words: pork jerky, tomato powder, total plate counts, lipid oxidation, colour, sensory properties.

\section{Introduction}

Present day consumers demand for meat products that are safe, nutritious, convenient, rich in variety, attractive in appearance, texture, odor and taste. The consumer preference for naturally derived colorants is associated with their image of being healthy (Hood and Riordan, 1973). Recent studies have indicated the potential health benefits of a diet rich in tomatoes and tomato products (Tapiero et al., 2004). Tomato and tomato products are rich source in lycopene and other carotenoids such as $\beta$ carotene, phytoene, phytofluene and lutein (Choski and Joshi, 2007; Goula and Adamopoulos, 2005; Kavanaugh et al., 2007; Tapiero et al., 2004). The ability of lycopene to act as a potent antioxidant is thought to be responsible for protecting cells against oxidative damage and thereby

\footnotetext{
*Corresponding author: Suk-Nam Kang, Department of Animal Resources Technology, Gyeongnam National University of Science and Technology, Jinju 660-758, Korea. Tel: 82-55-751-3512, Fax: 82-55-751-3280, E-mail: white@jinju.ac.kr
}

decreasing the risk of chronic diseases (Kavanaugh et al., 2007; Omoni and Aluko, 2005). Adding tomato, tomato products or lycopene to meat could lead to products with health benefit. Few studies have been reported regarding the use of tomato products or lycopene in meat and meat products. Østerlie and Lerfall (2005) studied the effect of lycopene from sun dried tomatoes, tomato paste and crystalline lycopene on the storage quality and colour of minced meat. Tomato paste also used in beef patties (Candogan, 2002) and frankfurters (Deda et al., 2007). Yilmaz et al. (2002) studied the influence of tomato juice on the quality characteristics of low-fat cooked sausages and Sánchez-Escalante et al. (2003) analysed the influence of addition of oleoresins of tomato and frozen tomato pulp on the colour and odour of beef patties. A number of studies have been conducted for making pork jerky (Han et al., 2007) and other meat jerky (Albright et al., 2003; Calicioglu et al., 2003; Lee and Kang 2003; Pegg et al., 2006) using various processing techniques. This stimulated the interest in manufacturing jerky by using new technologies and formulations, with different 
types of meat and reduced levels of nitrite, phosphate, salt and fat for health benefit (Desmond and Kenny, 2005).

The objective of the present study was to evaluate the effectiveness of different levels of tomato powder for inhibiting lipid oxidation and microbial growth and enhancing colour stability in pork jerky during storage at room temperature.

\section{Materials and Methods}

\section{Preparation of tomato powder}

Fresh tomatoes harvested in August 2007 were obtained from Agricultural Products Wholesale Market, Jinju city. After washing and dicing, tomatoes were dried using hotair drying method. Tomato paste $(5 \mathrm{~kg})$ was mixed with olive oil $(140 \mathrm{~mL})$, and dried at $80^{\circ} \mathrm{C}$ for $2 \mathrm{~h}$ followed by $60^{\circ} \mathrm{C}$ for $72 \mathrm{~h}$ using a hot-air drying oven (DMC-122SP; Daeil Engr. Co., Korea) finally containing around 3-5\% moisture. The dried tomato powder was then pulverized using a blender (3030, Hsign Feng Enterprise Factory, Taichung, Taiwan) and sieved through a No. 40 stainless steel sieve (40 mesh). The resulting tomato powders were then sealed and kept in $-40^{\circ} \mathrm{C}$. The tomato powder had colour values as lightness $\left(\mathrm{L}^{*}\right) 46.24$, redness $\left(\mathrm{a}^{*}\right)$ 8.26, yellowness $\left(b^{*}\right) 6.26$.

\section{Preparation of jerky}

Commercially available Longissimus dorsi (LD) muscles (20 kg) (Landrace×Yorkshire×Duroc; $100 \pm 5 \mathrm{~kg}$ ) were obtained from pork carcasses at $48 \mathrm{~h}$ postmortem from a local meat market. All subcutaneous and intermuscular fat and visible connective tissue were removed from the fresh muscles and sliced at $6 \mathrm{~mm}$ thickness with a meat slicer (HFS 350G, Handkook Fugee Indusrties Co. Ltd., Korea). This sliced LD divided into four equal-weight sections were cured in a cure solution containing $12 \%$ soy sauce, $5.4 \%$ sugar, $0.38 \%$ sesame oil, $1.2 \%$ ground garlic, $0.02 \%$ pepper (Hanil chemical Co., Korea), 1.0\% seasoning (based on raw meat weight; w/w) (MSC Co., Ltd., Gyonggi, Korea and added with tomato powder $0.0 \%$ (C), 1.0\% (T1), 1.5\% (T2) and 2.0\% (T3) (based on total weight; w/w). The final concentration of tomato powder $(2.0 \%)$ was decided by preliminary experiment mainly by sensory evaluation (especially bitterness score). The sliced meats and curing solutions were tumbled with tumbler (Vis-41, BIRO MFG Co., USA) for $12 \mathrm{~h}$. All cured muscle samples were dried using a single truck smokehouse (AC7FM-SMK, YUSUNG Industries INC, Korea) at a temperature of $75^{\circ} \mathrm{C}, 60 \%$ relative humidity for $4 \mathrm{~h}$. After drying and cooling $\left(2^{\circ} \mathrm{C}\right.$ for $\left.2 \mathrm{~h}\right)$ the jerky samples were loosely packed (about $200 \mathrm{~g}$ ) in water impermeable plastic bags (single package) and were stored in the dark at $25^{\circ} \mathrm{C}$ for up to $40 \mathrm{~d}$. Samples were analyzed on days 1 , 15,30 and 40 for the following parameters. The manufacture was carried out in duplicate with 3 observations except sensory evaluation.

\section{Determination of $\mathbf{p H}$}

$\mathrm{pH}$ measurements were determined by blending (T25B, IKA Sdn. Bhd., Malaysia) $10 \mathrm{~g}$ of ground samples with $90 \mathrm{~mL}$ distilled water for $30 \mathrm{~s}$ and readings were taken with $\mathrm{pH}$ meter (8603, Metrohm, Swiss).

\section{Determination of water activity}

Approximately $10 \mathrm{~g}$ of ground samples were put into a holding cup, and then three measurements were made with a water activity analyzer (LKM200A, Lokas Co., Korea) and the average readings were noted.

\section{TBARS determination}

The 2-thiobarbituric acid reactive substances (TBARS) test was estimated according to Tarladgis et al. (1960) with some modification. Briefly, two $g$ of ground sample was homogenized in a $50 \mathrm{~mL}$ centrifuge tube with a 50 $\mathrm{uL}$ of BHA (7.2\% in ethanol) and $20 \mathrm{~mL}$ of a thiobarbituric acid (TBA)/trichloroacetic acid (TCA) solution (20 $\mathrm{mM}$ TBA in $15 \%$ TCA) by using a homogenizer (IKA model T-25Basic, Malaysia). The homogenate was heated at $90^{\circ} \mathrm{C}$ for $15 \mathrm{~min}$ in water bath. After heating the samples were cooled on ice and centrifuged for $15 \mathrm{~min}$ at 2,000 rpm by using a centrifuge (UNION 5KR; Hanil Science Industrial, Co., Ltd., Korea). The absorbance of the supernatant was measured at $532 \mathrm{~nm}$ by using a spectrophotometer (Spectronic model Genesys 5, U.S.A.). The concentration malonaldehyde $(\mathrm{mg} / \mathrm{kg})$ on the basis of wet weight was calculated using a standard curve.

\section{Microbiological analyses}

Each sample was carried out in duplicate. $25 \mathrm{~g}$ samples were taken aseptically from each treatment, transferred to sterile plastic pouches and homogenized for $2 \mathrm{~min}$ at room temperature with $225 \mathrm{~mL}$ sterile $1 \%(\mathrm{w} / \mathrm{v})$ ringer solution using a stomacher Lab-Blender (78860 ST-Nom, Interscience, France). Appropriate dilutions of samples were prepared in 1\% Ringer solution blank and plated in duplicate onto plate count agar (PCA; Difco Lab) and incubated at $32^{\circ} \mathrm{C}$ for $48 \mathrm{~h}$ under aerobic condition for total bacterial count. Enterobacteriaceae and Escherichia 
coli were incubated on E. coli/Coliform count plate petrifilm (3M Health care, USA) at $30^{\circ} \mathrm{C}$ for $2 \mathrm{~d}$.

\section{Texture profile analysis (TPA)}

Texture profile analysis of eight samples $(0.60 \times 2.00 \times$ $2.0 \mathrm{~cm}$ ) cut from each samples was determined using an Instron 3343 (US/MX50, A\&D Co., USA) equipped with a standard cylindrical plate of diameter $0.25 \mathrm{~cm}$. Samples were equilibrated to room temperature and compressed twice to $70 \%$ of their original thickness at a constant speed of $60 \mathrm{~mm} / \mathrm{min}$. Texture profile parameters were calculated from the force-deformation curves, as follows: hardness $(\mathrm{kg}$; force necessary to attain a given deformation, maximum force), cohesiveness (dimensionless; ratio of the positive force area during the second compression to that during the first compression excluding the areas under the decompression portion of each cycle), gumminess $(\mathrm{kg}$; simulated energy required to disintegrate a semisolid food to a steady state, hardness $\times$ cohesiveness), springiness (ratio; ratio of distances that the samples recover after the first compression), and chewiness (kg; hardness $\times$ cohesiveness $\times$ springiness).

\section{Colour measurement}

Color was measured using a spectrocolourimeter (CR 400, Minolta Co., Japan) calibrated with a white plate and light trap supplied by the manufacturer. Colour was expressed using the CIE L*, a*, b* colour system (CIE, 1976).

\section{Sensory evaluation}

The samples were served to 12 experienced panel members. The manufacture was carried out in duplicate by sensory panelist. A preparatory session was held prior to testing so that each panel member could thoroughly discuss and clarify each attribute to be evaluated. Testing was initiated after the panelists agreed on the specifications. The samples were cut into pieces of $2 \times 2 \times 0.5 \mathrm{~cm}^{3}$ and served to each panelist separately under white illumination. Panelists were presented with randomly coded samples. The colour, aroma ( $1=$ extremely undesirable, 9 $=$ extremely desirable), juiciness ( $1=$ extremely dry, $9=$ extremely juicy) and overall acceptability (1=extremely undesirable, $9=$ extremely desirable) of the samples were evaluated using 9-point descriptive scale. Panelists were required to cleanse their palate between samples with water.

\section{Statistical analysis}

An analysis of variance were performed on all the vari- ables measured using the general linear model (GLM) procedure of the SAS statistical package (1999). The Duncan's multiple range test $(p<0.05)$ was used to determine differences between treatment means.

\section{Results and Discussion}

\section{Physicochemical analyses}

Table 1 shows the results for $\mathrm{pH}$, water activity $\left(\mathrm{a}_{\mathrm{w}}\right)$, TBARS and total plate counts (TPC) values in jerky added with tomato powder during storage at $25^{\circ} \mathrm{C}$. The $\mathrm{pH}$ values of tomato powder treated samples changed significantly $(p<0.05)$ lower than the control during storage except at day 1 of storage. A decrease in the $\mathrm{pH}$ value of meat products containing tomato paste have been reported by Candogan (2002) and Deda et al. (2007). They described that the decrease was due to the low $\mathrm{pH}$ of tomato paste added at high concentrations (10 to $15 \%$ ). In our study also the reduction of $\mathrm{pH}$ must be due to the low $\mathrm{pH}$ value

Table 1. Physicochemical and microbiological quality of pork loin jerky with tomato powder during storage at room temperature $\left(25^{\circ} \mathrm{C}\right)$

\begin{tabular}{|c|c|c|c|c|c|c|}
\hline & \multirow{2}{*}{$\begin{array}{l}\text { Treat- } \\
\text { ments }\end{array}$} & \multicolumn{5}{|c|}{ Storage (d) } \\
\hline & & 1 & 15 & 30 & 40 & SE \\
\hline \multirow{5}{*}{$\mathrm{pH}$} & $\mathrm{C}$ & $5.65^{\mathrm{a}}$ & $5.67^{\mathrm{a}}$ & $5.68^{\mathrm{a}}$ & $5.65^{\mathrm{a}}$ & 0.01 \\
\hline & $\mathrm{T} 1$ & $5.65^{\mathrm{Aa}}$ & $5.63^{\mathrm{Ab}}$ & $5.62^{\mathrm{Ab}}$ & $5.59^{\mathrm{Bb}}$ & 0.03 \\
\hline & $\mathrm{T} 2$ & $5.65^{\mathrm{Aa}}$ & $5.53^{\mathrm{Bc}}$ & $5.61^{\mathrm{Ab}}$ & $5.53^{\mathrm{Bc}}$ & 0.01 \\
\hline & $\mathrm{T} 3$ & $5.61^{\mathrm{b}}$ & $5.59^{\mathrm{c}}$ & $5.57^{\mathrm{c}}$ & $5.62^{\mathrm{b}}$ & 0.02 \\
\hline & SE & 0.01 & 0.01 & 0.03 & 0.01 & \\
\hline \multirow{5}{*}{$a_{w}$} & C & $0.67^{\mathrm{Ad}}$ & $0.65^{\mathrm{Bb}}$ & $0.64^{\mathrm{Cb}}$ & $0.63^{\mathrm{Cc}}$ & 0.03 \\
\hline & $\mathrm{T} 1$ & $0.71^{\mathrm{Ab}}$ & $0.66^{\mathrm{Bb}}$ & $0.66^{\mathrm{Bb}}$ & $0.66^{\mathrm{Bb}}$ & 0.01 \\
\hline & $\mathrm{T} 2$ & $0.69^{\mathrm{Ac}}$ & $0.64^{\mathrm{Bb}}$ & $0.65^{\mathrm{Bb}}$ & $0.64^{\mathrm{Bc}}$ & 0.05 \\
\hline & $\mathrm{T} 3$ & $0.75^{\mathrm{Aa}}$ & $0.73^{\mathrm{Ba}}$ & $0.71^{\mathrm{Ca}}$ & $0.69^{\mathrm{Ca}}$ & 0.04 \\
\hline & SE & 0.08 & 0.03 & 0.06 & 0.07 & \\
\hline \multirow{5}{*}{$\begin{array}{l}\text { TBARS } \\
(\mathrm{mg} / \mathrm{kg})\end{array}$} & $\mathrm{C}$ & 0.45 & 0.42 & 0.46 & 0.45 & 0.08 \\
\hline & $\mathrm{T} 1$ & 0.41 & 0.37 & 0.42 & 0.42 & 0.09 \\
\hline & $\mathrm{T} 2$ & 0.45 & 0.41 & 0.40 & 0.36 & 0.08 \\
\hline & $\mathrm{T} 3$ & 0.46 & 0.49 & 0.45 & 0.43 & 0.08 \\
\hline & SE & 0.08 & 0.09 & 0.07 & 0.08 & \\
\hline \multirow{5}{*}{$\begin{array}{c}\text { TPC } \\
\text { (Log } \\
\text { CFU/g) }\end{array}$} & $\mathrm{C}$ & $1.48^{\mathrm{Ba}}$ & $2.14^{\mathrm{Aa}}$ & $1.36^{\mathrm{Ba}}$ & $1.46^{\mathrm{Ba}}$ & 0.19 \\
\hline & $\mathrm{T} 1$ & $1.00^{\mathrm{Bb}}$ & $1.48^{\mathrm{Ab}}$ & $1.00^{\mathrm{Bb}}$ & $0.00^{\mathrm{Cc}}$ & 0.11 \\
\hline & $\mathrm{T} 2$ & $0.33^{\mathrm{b}}$ & $1.13^{\mathrm{b}}$ & $0.93^{\mathrm{b}}$ & $1.20^{\mathrm{b}}$ & 0.15 \\
\hline & $\mathrm{T} 3$ & $0.00^{\mathrm{Bb}}$ & $1.19^{\mathrm{Ab}}$ & $0.67^{\mathrm{Ab}}$ & $1.00^{\mathrm{Ab}}$ & 0.17 \\
\hline & SE & 0.11 & 0.16 & & & \\
\hline
\end{tabular}

$\mathrm{a}_{\mathrm{w}}$, water activity; TBARS, 2-thiobarbituric acid reactive substances; TPC, total plate counts; SE, Pooled standard errors of the mean; $\mathrm{C}, \mathrm{T}_{1}, \mathrm{~T}_{2}, \mathrm{~T}_{3}$, treatments with $0,1,1.5$ and $2 \%$ tomato powder, respectively on raw meat weight basis.

${ }^{\mathrm{A}-\mathrm{C}}$ Means with different superscripts in the same row differ significantly $(p<0.05)$.

${ }^{\mathrm{a}-\mathrm{c}}$ Means with different superscripts in the same column differ significantly $(p<0.05)$. 
of tomato powder (3.48).

It is important to control the water content because water activity is closely related to water content (Leistner, 1987). At day 1 of storage, water activity values of treated samples were significantly $(p<0.05)$ higher than the control. At day 15 of storage water activities of all samples decreased compared to that of day 1 of storage. The water activity values of T3 were comparatively higher than the others during storage $(p<0.05)$. Water activity is useful to describe the thermodynamic equilibrium state of jerky (Labuza and Busk, 1979; Rockland and Nishi, 1980), and affect texture profiles and microbial counts of food stuff. Thus, the additives of manufacturing process have an important effect on the water activity and the quality of the product during storage. It is widely accepted that many food spoilage bacteria are unable to multiply at aw value below 0.95 and growth of most microorganisms is retarded or inhibited below aw at 0.90 (Leistner and Rodel, 1976). In this result, the ultimate aw of the finished products varied between 0.63 and 0.75 .

There were no significant differences among all tested samples with regard to TBARS during storage. These results were disagreed with those reported by Condogan (2002) who found that in beef patties, produced without the use of sodium nitrite, the treatments with $5 \%, 10 \%$ and $15 \%$ tomato paste had lower $(p<0.05)$ TBARS values than the control, due to the antioxidative activity of lycopene present in tomato paste. This difference in results might be due to the different sample used and the processing method (addition materials, processing temperature and final products).

\section{Microbiological analyses}

The coliform and E.coli were not detected in all samples during storage. However, total plate counts of tomato powder treated samples were significantly $(p<0.05)$ lower than the control during storage. Total plate count shows the overall microbial quality of the product and it is more important when the product is stored at room temperature. The lower microbial levels seem to be due to the fact that microbial growth is inhibited at lower $\mathrm{pH}$ value. In agreement with our findings of lower $\mathrm{pH}$ values to reduce microbial growth has been reported earlier (Drosinos and Board, 1995; Kennedy et al., 2005; Vergara and Gallego, 2001). This result indicates the positive effect of using tomato powder for the product as an antibacterial ingredient.

\section{Instrumental Surface colour}

Table 2 shows the results for surface colour values of jerky added with tomato powder during storage. Jerky colour is the most important factor affecting consumer acceptance, purchasing decisions and satisfaction of meat products. The changes observed in colour parameters (Table 2) were mainly related to the concentration of tomato powder. Jerky with tomato powder had slightly lower values for lightness $\left(\mathrm{L}^{*}\right)$ but higher $(p<0.05)$ for redness $\left(\mathrm{a}^{*}\right)$ and yellowness $\left(b^{*}\right)$ than the jerky without tomato powder during storage. These products have improved red colour and are more attractive to consumers than the control samples. According to Candogan (2002), this colour improving effect of tomato paste can be attributed to the pigment, lycopene, which is present in tomato paste, due to its red colour. Similar results have been reported by Calvo et al. (2008). Furthermore, Østerlie and Lerfall (2005) indicated that mixing minced meat with a lycopene containing product could reduce or replace the use of nitrite.

\section{Instrumental Texture}

Table 3 shows the results for texture profile of jerky added with tomato powder during storage. In all cases hardness values increased when tomato powder was added in T2 and T3 samples at day 1 and 15 of storage and in T3

Table 2. Changes in instrumental surface colour of pork loin jerky with tomato powder during storage at room temperature

\begin{tabular}{|c|c|c|c|c|c|c|}
\hline & \multirow{2}{*}{$\begin{array}{l}\text { Treat- } \\
\text { ments }\end{array}$} & \multicolumn{5}{|c|}{ Storage (d) } \\
\hline & & 1 & 15 & 30 & 40 & SE \\
\hline \multirow{5}{*}{$\begin{array}{c}\mathrm{L}^{*} \\
\text { (Lightness) }\end{array}$} & $\mathrm{C}$ & $26.43^{a}$ & $26.81^{\mathrm{a}}$ & 26.89 & $25.83^{\mathrm{a}}$ & 0.57 \\
\hline & $\mathrm{T} 1$ & $25.95^{\mathrm{a}}$ & $24.59^{\mathrm{b}}$ & 25.00 & $25.38^{\mathrm{a}}$ & 0.44 \\
\hline & $\mathrm{T} 2$ & $24.42^{\mathrm{b}}$ & $24.35^{\mathrm{b}}$ & 26.46 & $24.30^{\mathrm{b}}$ & 1.00 \\
\hline & $\mathrm{T} 3$ & $23.21^{\mathrm{b}}$ & $24.35^{\mathrm{b}}$ & 26.05 & $24.49^{\mathrm{b}}$ & 0.20 \\
\hline & SE & 0.44 & 0.40 & 0.90 & 0.47 & \\
\hline \multirow{5}{*}{$\begin{array}{c}\mathrm{a}^{*} \\
\text { (Redness) }\end{array}$} & C & $7.48^{\mathrm{b}}$ & $8.24^{\mathrm{b}}$ & $8.23^{\mathrm{c}}$ & $8.48^{\mathrm{c}}$ & 0.58 \\
\hline & $\mathrm{T} 1$ & $9.10^{\mathrm{a}}$ & $9.25^{\mathrm{a}}$ & $9.36^{\mathrm{b}}$ & $10.09^{b}$ & 0.40 \\
\hline & $\mathrm{T} 2$ & $11.85^{\mathrm{Aa}}$ & $9.48^{\mathrm{Ba}}$ & $9.37^{\mathrm{Bb}}$ & $12.29^{\mathrm{Aa}}$ & 0.33 \\
\hline & $\mathrm{T} 3$ & $11.17^{\mathrm{a}}$ & $10.56^{\mathrm{a}}$ & $10.64^{\mathrm{a}}$ & $11.26^{\mathrm{a}}$ & 0.67 \\
\hline & SE & 0.46 & 0.44 & 0.64 & 0.57 & \\
\hline \multirow{5}{*}{$\begin{array}{c}\mathrm{b}^{*} \\
\text { (Yellow- } \\
\text { ness) }\end{array}$} & C & $4.15^{\mathrm{c}}$ & $4.31^{\mathrm{c}}$ & $3.22^{\mathrm{b}}$ & $4.41^{\mathrm{c}}$ & 0.27 \\
\hline & $\mathrm{T} 1$ & $4.33^{\mathrm{b}}$ & $4.90^{\mathrm{b}}$ & $5.33^{\mathrm{a}}$ & $4.97^{\mathrm{b}}$ & 0.41 \\
\hline & $\mathrm{T} 2$ & $4.75^{\mathrm{Bb}}$ & $4.99^{\mathrm{Bb}}$ & $5.57^{\mathrm{Aa}}$ & $6.76^{\mathrm{Aa}}$ & 0.54 \\
\hline & $\mathrm{T} 3$ & $5.39^{\mathrm{a}}$ & $5.72^{\mathrm{a}}$ & $5.08^{\mathrm{a}}$ & $5.75^{\mathrm{a}}$ & 0.44 \\
\hline & SE & 0.57 & 0.39 & 0.46 & 0.45 & \\
\hline
\end{tabular}

SE, Pooled standard errors of the mean; $\mathrm{C}, \mathrm{T}_{1}, \mathrm{~T}_{2}, \mathrm{~T}_{3}$, treatments added with $0,1,1.5$ and $2 \%$ tomato powder, respectively on raw meat weight basis

${ }^{A-C}$ Means with different superscripts in the same row differ significantly $(p<0.05)$.

${ }^{\mathrm{a}-\mathrm{c}}$ Means with different superscripts in the same column differ significantly $(p<0.05)$. 
at day 40 of storage. Similar results have been reported by Calvo et al. (2008). The increase of hardness could be explained by the presence of fiber in the tomato peel and the lower $\mathrm{pH}$. This is composed mainly of cellulose and lignin, which could modify the textural properties yielding a harder jerky. Similar result was obtained by García et al. (2002) when adding cereals and fruit fibre to dry and cooked sausages. They reported a marked increase in hardness when wheat or oat fibres were added to dry fermented sausages, as a consequence of their insoluble

Table 3. Instrumental texture analyses of pork loin jerky with tomato powder during storage at room temperature

\begin{tabular}{|c|c|c|c|c|c|c|}
\hline & \multirow{2}{*}{$\begin{array}{l}\text { Treat- } \\
\text { ments }\end{array}$} & \multicolumn{5}{|c|}{ Storage (d) } \\
\hline & & 1 & 15 & 30 & 40 & SE \\
\hline \multirow{5}{*}{$\begin{array}{l}\text { Hardness } \\
\quad(\mathrm{kg})\end{array}$} & $\mathrm{C}$ & $3.21^{\mathrm{b}}$ & $2.05^{\mathrm{b}}$ & 3.04 & $2.78^{b}$ & 0.26 \\
\hline & $\mathrm{T} 1$ & $4.28^{\mathrm{a}}$ & $2.13^{\mathrm{b}}$ & 2.33 & $2.46^{\mathrm{b}}$ & 0.31 \\
\hline & $\mathrm{T} 2$ & $3.75^{\mathrm{a}}$ & $2.34^{\mathrm{a}}$ & 2.35 & $2.43^{b}$ & 0.26 \\
\hline & $\mathrm{T} 3$ & $3.74^{\mathrm{a}}$ & $3.60^{\mathrm{a}}$ & 3.40 & $3.35^{\mathrm{a}}$ & 0.21 \\
\hline & SE & 0.21 & 0.35 & 0.24 & 0.29 & \\
\hline \multirow{5}{*}{$\begin{array}{l}\text { Cohesive- } \\
\text { ness }\end{array}$} & $\mathrm{C}$ & 2.52 & 3.44 & 3.04 & $2.65^{\mathrm{b}}$ & 0.30 \\
\hline & $\mathrm{T} 1$ & 3.27 & 2.12 & 2.33 & $2.56^{\mathrm{b}}$ & 0.31 \\
\hline & $\mathrm{T} 2$ & 2.72 & 2.32 & 2.78 & $2.41^{\mathrm{b}}$ & 0.22 \\
\hline & T3 & 3.74 & 3.58 & 3.40 & $3.31^{\mathrm{a}}$ & 0.21 \\
\hline & $\mathrm{SE}$ & 0.22 & 0.35 & 0.19 & 0.29 & \\
\hline \multirow{5}{*}{$\begin{array}{l}\text { Springi- } \\
\text { ness }\end{array}$} & $\mathrm{C}$ & $1.21^{\mathrm{a}}$ & 1.02 & 1.46 & $1.32^{\mathrm{a}}$ & 0.05 \\
\hline & $\mathrm{T} 1$ & $1.27^{\mathrm{a}}$ & 1.07 & 1.28 & $1.21^{\mathrm{b}}$ & 0.05 \\
\hline & $\mathrm{T} 2$ & $0.97^{\mathrm{b}}$ & 1.01 & 1.14 & $1.19^{\mathrm{b}}$ & 0.06 \\
\hline & $\mathrm{T} 3$ & $1.08^{\mathrm{b}}$ & 1.10 & 1.38 & $1.15^{\mathrm{b}}$ & 0.06 \\
\hline & SE & 0.07 & 0.06 & 0.06 & 0.05 & \\
\hline \multirow{5}{*}{$\begin{array}{c}\text { Gummi- } \\
\text { ness } \\
(\mathrm{kg})\end{array}$} & $\mathrm{C}$ & $0.84^{\mathrm{A}}$ & $0.68^{\mathrm{B}}$ & $0.62^{\mathrm{Ba}}$ & $0.73^{\mathrm{Ba}}$ & 0.08 \\
\hline & $\mathrm{T} 1$ & $0.85^{\mathrm{A}}$ & $0.47^{\mathrm{B}}$ & $0.42^{\mathrm{Bb}}$ & $0.47^{\mathrm{Bb}}$ & 0.07 \\
\hline & $\mathrm{T} 2$ & $0.65^{\mathrm{A}}$ & $0.31^{\mathrm{B}}$ & $0.24^{\mathrm{Bb}}$ & $0.38^{\mathrm{Bb}}$ & 0.06 \\
\hline & T3 & $0.59^{\mathrm{A}}$ & $0.50^{\mathrm{B}}$ & $0.29^{\mathrm{Cb}}$ & $0.36^{\mathrm{Cb}}$ & 0.05 \\
\hline & SE & 0.08 & 0.08 & 0.08 & 0.04 & \\
\hline \multirow{5}{*}{$\begin{array}{l}\text { Chewi- } \\
\text { ness } \\
(\mathrm{kg})\end{array}$} & $\mathrm{C}$ & $1.04^{\mathrm{A}}$ & $0.63^{\mathrm{B}}$ & $0.74^{\mathrm{Ba}}$ & $0.78^{\mathrm{Ba}}$ & 0.12 \\
\hline & $\mathrm{T} 1$ & $1.08^{\mathrm{A}}$ & $0.63^{\mathrm{B}}$ & $0.53^{\mathrm{Bb}}$ & $0.52^{\mathrm{Bb}}$ & 0.08 \\
\hline & $\mathrm{T} 2$ & $0.66^{\mathrm{A}}$ & $0.42^{\mathrm{B}}$ & $0.30^{\mathrm{Bb}}$ & $0.43^{\mathrm{Bc}}$ & 0.08 \\
\hline & T3 & $0.72^{\mathrm{A}}$ & $0.55^{\mathrm{B}}$ & $0.38^{\mathrm{Bb}}$ & $0.55^{\mathrm{Bb}}$ & 0.06 \\
\hline & SE & 0.11 & 0.11 & 0.08 & 0.04 & \\
\hline \multirow{5}{*}{$\begin{array}{c}\text { Adhesive- } \\
\text { ness } \\
(\mathrm{kg})\end{array}$} & $\mathrm{C}$ & 1.03 & 1.31 & 0.69 & 0.98 & 0.10 \\
\hline & $\mathrm{T} 1$ & 0.99 & 1.14 & 0.85 & 0.89 & 0.14 \\
\hline & $\mathrm{T} 2$ & 1.02 & 0.93 & 0.83 & 0.93 & 0.08 \\
\hline & T3 & 1.19 & 0.90 & 0.94 & 0.98 & 0.09 \\
\hline & SE & 0.11 & 0.08 & 0.10 & 0.14 & \\
\hline
\end{tabular}

SE, Pooled standard errors of the mean; $\mathrm{C}, \mathrm{T}_{1}, \mathrm{~T}_{2}, \mathrm{~T}_{3}$, treatments added with $0,1,1.5$ and $2 \%$ tomato powder, respectively on raw meat weight basis.

${ }^{\mathrm{A}-\mathrm{C}}$ Means with different superscripts in the same row differ significantly $(p<0.05)$.

${ }^{a-c}$ Means with different superscripts in the same column differ significantly $(p<0.05)$. dietary fibre content. Significantly $(p<0.05)$ higher values were found in gumminess and chewiness values in the treated jerky than control at day 30 and 40 of storage. In the case of gumminess and chewiness values, the fibre could cause a difference in the opposite direction since the components of this type of fibre have a complex structure, even crystalline making it easier to break into small pieces in the mouth favoring mastication.

\section{Sensory analysis}

According to the sensory evaluation results (Table 4),

Table 4. Sensory analyses of pork loin jerky with tomato powder during storage at room temperature

\begin{tabular}{|c|c|c|c|c|c|c|}
\hline & \multirow{2}{*}{$\begin{array}{l}\text { Treat- } \\
\text { ments }\end{array}$} & \multicolumn{5}{|c|}{ Storage $(d)$} \\
\hline & & 1 & 15 & 30 & 40 & SE \\
\hline \multirow{5}{*}{ Colour } & $\mathrm{C}$ & 6.80 & 6.60 & 6.70 & $6.50^{\mathrm{b}}$ & 0.12 \\
\hline & $\mathrm{T} 1$ & 6.50 & 6.50 & 6.50 & $6.67^{\mathrm{ab}}$ & 0.13 \\
\hline & $\mathrm{T} 2$ & 6.20 & 6.20 & 6.20 & $6.40^{\mathrm{ab}}$ & 0.12 \\
\hline & T3 & 6.00 & 6.58 & 6.53 & $7.17^{\mathrm{a}}$ & 0.16 \\
\hline & $\mathrm{SE}$ & 0.14 & 0.10 & 0.08 & 0.17 & \\
\hline \multirow{5}{*}{ Flavor } & $\mathrm{C}$ & 6.80 & 6.80 & 6.70 & 7.20 & 0.16 \\
\hline & $\mathrm{T} 1$ & 6.67 & 6.58 & 6.83 & 6.67 & 0.17 \\
\hline & $\mathrm{T} 2$ & 6.00 & 6.50 & 6.60 & 6.40 & 0.19 \\
\hline & $\mathrm{T} 3$ & 6.33 & 6.17 & 6.25 & 6.25 & 0.20 \\
\hline & SE & 0.19 & 0.22 & 0.13 & 0.16 & \\
\hline \multirow{5}{*}{ Aroma } & $\mathrm{C}$ & 6.80 & 6.70 & 6.50 & 6.90 & 0.14 \\
\hline & $\mathrm{T} 1$ & 6.17 & 6.00 & 6.25 & 6.25 & 0.14 \\
\hline & $\mathrm{T} 2$ & 6.40 & 6.40 & 6.40 & 6.20 & 0.14 \\
\hline & $\mathrm{T} 3$ & 6.00 & 6.17 & 6.00 & 6.67 & 0.16 \\
\hline & SE & 0.15 & 0.16 & 0.09 & 0.13 & \\
\hline \multirow{5}{*}{ Tenderness } & $\mathrm{C}$ & 4.60 & 4.70 & 4.10 & 4.60 & 0.27 \\
\hline & $\mathrm{T} 1$ & 5.58 & 5.58 & 5.75 & 5.08 & 0.25 \\
\hline & $\mathrm{T} 2$ & 5.60 & 5.20 & 5.00 & 5.40 & 0.26 \\
\hline & T3 & 4.92 & 4.75 & 4.83 & 5.17 & 0.24 \\
\hline & $\mathrm{SE}$ & 0.31 & 0.20 & 0.18 & 0.26 & \\
\hline \multirow{5}{*}{ Juiciness } & $\mathrm{C}$ & 4.60 & 4.40 & 4.20 & 4.60 & 0.27 \\
\hline & $\mathrm{T} 1$ & 5.83 & 6.00 & 6.17 & 5.67 & 0.26 \\
\hline & $\mathrm{T} 2$ & 5.40 & 5.60 & 5.40 & 5.70 & 0.27 \\
\hline & $\mathrm{T} 3$ & 4.33 & 4.00 & 4.42 & 4.42 & 0.27 \\
\hline & $\mathrm{SE}$ & 0.29 & 0.16 & 0.15 & 0.28 & \\
\hline \multirow{5}{*}{$\begin{array}{c}\text { Overall } \\
\text { acceptability }\end{array}$} & $\mathrm{C}$ & 6.60 & 6.60 & 6.50 & 7.40 & 0.15 \\
\hline & $\mathrm{T} 1$ & 6.58 & 6.50 & 6.92 & 6.50 & 0.17 \\
\hline & $\mathrm{T} 2$ & 6.00 & 6.10 & 6.20 & 6.50 & 0.18 \\
\hline & T3 & 5.83 & 6.25 & 6.50 & 6.58 & 0.17 \\
\hline & SE & 0.17 & 0.19 & 0.16 & 0.13 & \\
\hline
\end{tabular}

SE, Pooled standard errors of the mean; Sensory scores were assessed on 9 point scale where $1=$ extremely bad or slight, $9=$ =xtremely good or much; $C, T_{1}, T_{2}, T_{3}$, treatments added with $0,1,1.5$ and $2 \%$ tomato powder, respectively on raw meat weight basis.

${ }^{a, b}$ Means with different superscripts in the same column significantly differ at $p<0.05$. 
the scores of T3 was better than those of control at day 40 of storage, but no samples showed significant difference for aroma, flavor, tenderness, juiciness and overall acceptability values during the storage period. These results agreed with those of Hoe et al. (2006) who found that the $0.5 \%$ tomato powder did not changed the sensory characteristics of emulsion type sausages. Desmond et al. (1998) reported that the oat fibre aided in water retention, produced juicier low-fat beef patties.

In conclusion, Pork jerky prepared with tomato powder showed slightly higher water activity, redness and yellowness, hardness, chewiness and gumminess values and lower lightness and total plate counts compared to controls during storage. However there were no significant differences between the treatment and control products in TBARS values and in sensory scores during storage.

\section{Acknowledgements}

This research was supported by Grant from the Korean Rural Development Administration (Agenda Program, 200901OFT092760244), Korea Sanhak Fundation and Priority Research Centers Program through the National Research Foundation of Korea (NRF) funded by the Ministry of Education, Science and Technology (20120006683).

\section{References}

1. Albright, S. N., Kendall. P. A., Avens. J. S., and Sofos, J. N. (2003) Pretreatment effect on inactivation of Escherichia coli O157:H7 inoculated beef jerky. LWT-Food Sci. Technol. 36, 381-389.

2. Calicioglu, M., Sofos, J. N., and Kendall, P. A. (2003) Influence of marinades on survival during storage of acid-adapted and nonadapted Listeria monocytogenes inoculated postdrying on beef jerky. Inter. J. Food. Microbiol. 86, 283-292.

3. Calvo, M. M., Garciía, M. L., and Selgas, M. D. (2008) Dry fermented sausages enriched with lycopene from tomato peel. Meat Sci. 80, 167-172.

4. Candogan, K. (2002) The effect of tomato paste on some quality characteristics of beef patties during refrigerated storage. Eur. Food Res. and Technol. 215, 305-309.

5. Choski, P. M., and Joshi, V. Y. (2007) A review on lycopene -Extraction, purification, stability and applications. Inter. $J$. Food Properties 10, 289-298.

6. CIE (1976) Official recommendations on uniform color spaces color difference equations and metric color terms, Suppl. No. 2. CIE (Commission International de l'Éclairage) Publication No. 15 Colorimetry, Paris.

7. Deda, M. S., Bloukas, J. G., and Fista, G. A. (2007) Effect of tomato paste and nitrite level on processing and quality char- acteristics of frankfurters. Meat Sci. 76, 501-508.

8. Desmond, E., Troy, D., and Buckley, D. (1998) The effects of tapioca starch, oat fibre and whey protein on the physical and sensory properties of low-fat beef burgers. Lebensmittel Wissenschaft und Technologie. 31, 653-657.

9. Desmond, E. M. and Kenny, T. A. (2005) Effect of pelvic suspension and cooking method on the processing and sensory properties of hams prepared from two pork muscles. Meat Sci. 69, 425-431.

10. Drosinos, E. H. and Board, R. G. (1995) A survey of minced lamb packaged in modified atmospheres. Fleischwirtsch 3, 11-15.

11. García, M. L., Domínguez, R., Gálvez, M. D., Casas, C., and Selgas, M. D. (2002) Utilization of cereal and fruit fibres in low fat fermented sausages. Meat Sci. 60, 27-236.

12. Goula, A. M. and Adamopoulos, K. G. (2005) Stability of lycopene during spray drying of tomato pulp. Lebensmittell Wissenschaft und Technologie 38, 479-487.

13. Han, D. J., Jeong. J. Y., Choi, J. H., Choi, Y. S., Kim, H. Y., and Lee, M. A. (2007) Effects of drying conditions on quality properties of pork jerky. Korean J. Food Sci. Ani. 27, 2934.

14. Hoe, S. K., Park, K. H., Yang, M. R., Jeong, K. J., Kim, D. H., Choi, S. K., and Kim, I. S. (2006) Quality characteristics of low-fat emusified sausage containing tomatoes during cold storage. Korean J. Food. Sci. Ani. 26, 297-305.

15. Hood, D. E. and Riordan, E. B. (1973) Discolouration in prepackaged beef: measurement by reflectance spectrophotometers and shopper discrimination. J. Food Technol. 8, 333343.

16. Kavanaugh, C. J., Trumbo, P. R., and Ellwood, K. C. (2007) The US food and drug administration's evidence-based review for qualified health claims: Tomatoes, lycopene and cancer. J. National Cancer Institute 99, 1074-1085.

17. Kennedy, C., Buckley, D. J., and Kerry, J. P. (2005) Influence of different gas compositions on the short-term, storage stability of mother-packaged retail-ready lamb packs. Meat Sci. 69, 27-33.

18. Labuza, T. P. and Busk, G. C. (1979) Analysis of the water binding in gels. J. Food Sci. 44, 1379-1385.

19. Lee, S. W. and Kang, C. S. (2003) Effects of moisture content and drying temperature on the physicochemical properties of ostrich jerky. Nahrung Food 47, 330-333.

20. Leistner, L. (1987) Shelf stable product and intermediate moisture foods based on meat. In: Water activity theory and application to food. Rockland, L., and Beuchat, L. B. (eds). Marcel Dekker Inc, New York, pp. 295-328.

21. Leistner, L. and Rodel, W. (1976) The stability of intermediate moisture foods with respect to microorganisms. In: Intermediate moisture foods. Davies, R., Birch, G., and Parker, K. (eds). Elsevier Applied Science, London, pp. 120-137.

22. Omoni, A. O., and Aluko, R. E. (2005) The anti-carcinogenic and anti-atherogenic effects of lycopene: a review. Trends Food Sci. Technol. 16, 334-350.

23. Østerlie, M. and Lerfall, J. (2005) Lycopene from tomato products added minced meat. Effect on storage quality and 
colour. Food Res. Inter. 38L, 925-929.

24. Pegg, R. B., Amarowicz, R., and Code, W. E. (2006) Nutritional characteristics of emu (Dromaius novaehollandiae) meat and its value-added products. Food Chem. 97, 193-202

25. Rockland, L. B. and Nishi, S. K. (1980) Influence of water activity on food product quality and stability. Food Technol. 34, 42-51.

26. Sánchez-Escalante, A., Torrescano, G., Djenane, D., Beltrán, J. A., and Roncalés, P. (2003) Stabilization of colour and odour of beef patties using lycopene-rich tomato and peppers as a source of antioxidants. J. Sci Food Agri. 83, 187-194.

27. SAS (1999) SAS/STAT Software for PC. Release 6.11, SAS Institute, Cary, NC, USA

28. Tapiero, H., Townsend, M. D., and Tew, W. D. (2004) The role of carotenoids in the prevention of human pathologies.
Biomed. Pharmacoth. 58, 100-110.

29. Tarladgis, B. G., Watts, B. M., Younathan, M. T., and Dugan, L. A. (1960) Distillation method for the quantitative determination of malonaldehyde in racid foods. J. Am. Oil. Chem. Soc. 37, 44-52.

30. Vergara, H. and Gallego, L. (2001) Effects of gas composition in modified atmosphere packaging on the meat quality of Spanish Manchega lamb. J. Sci. Food Agri. 81, 1353-1357.

31. Yilmaz, I., Simsek, O., and Isikli, M. (2002) Fatty acid composition and quality characteristics of low-fat cooked sausages made with beef and chicken meat, tomato juice and sunflower oil. Meat Sci. 62, 253-258.

(Received 2012.6.12/Revised 1st 2012.9.26, 2nd 2012.10.23/ Accepted 2012.11.2) 